\title{
Grit, Persepsi Dukungan Organisasi, Karakteristik Pekerjaan dan Pengaruhnya terhadap Kualitas Hidup
}

\author{
Grit, Perceived Organizational Support, Job Characteristics and Their Effect on \\ Quality of Life
}

\author{
Laili Irawati \\ Fakultas Psikologi. Universitas Tarumanagara, Jakarta \\ e-mail: laili.irawati@gmail.com \\ Rostiana* \\ Fakultas Psikologi. Universitas Tarumanagara, Jakarta \\ e-mail: rostiana@fpsi.untar.ac.id
}

\begin{abstract}
Working as an IT employee who must meet Service Level Agreement (SLA) to customers means having to do the best for customers even though they are no longer in working hours. This way of working will ultimately affect the quality of life. Therefore, this study aims to determine which of the grit, perceived organizational support and job characteristics will affect the quality of life of IT employees. This research was conducted using a non-probability sampling technique, namely employees who work in the IT department who have service standards to customers in carrying out their work. Research data collection was carried out twice with a data collection time of 1 to 3 weeks between the first study and the second study. The number of participants in the first study was 199 people and the second study was 128 people. The results showed that job characteristics became the dominant factor affecting the quality of life of IT employees. Meanwhile, grit and perceived organizational support do not affect the quality of life of IT employees. With about 70 percent of the study participants being male, it is understandable if work becomes an important part of a person's life so that even though he works with high work demands he still feels he has a good quality of life.
\end{abstract}

Keywords: quality of life, grit, perceived organizational support, job characteristics.

\begin{abstract}
ABSTRAK
Bekerja sebagai karyawan IT yang harus memenuhi standar layanan kepada pelanggan berarti harus melakukan yang terbaik bagi pelanggan meskipun sudah tidak lagi di jam kerja. Cara kerja seperti ini pada akhirnya akan berpengaruh terhadap kualitas hidup. Oleh karena itu, penelitian ini bertujuan untuk mengetahui manakah dari grit, persepsi dukungan organisasi dan karakteristik pekerjaan yang akan mempengaruhi kualitas hidup karyawan IT. Penelitian ini dilakukan dengan teknik pengambilan sampel nonprobability sampling yaitu pada karyawan yang bekerja di bagian IT yang memiliki standar layanan kepada pelanggan dalam melakukan pekerjaannya. Pengambilan data penelitian dilakukan dua kali dengan jeda waktu pengambilan data 1 sampai 3 minggu antara studi kesatu dan studi kedua. Jumlah partisipan pada studi kesatu 199 orang dan studi kedua 128 orang. Hasil penelitian menunjukkan bahwa karakteristik pekerjaan menjadi faktor yang dominan mempengaruhi kualitas hidup karyawan IT. Sedangkan grit dan persepsi dukungan organisasi tidak berpengaruh terhadap kualitas hidup karyawan IT. Dengan sekitar 70 persen peserta penelitian berjenis kelamin laki-laki, dapat dipahami jika pekerjaan menjadi bagian penting kehidupan seseorang sehingga meskipun bekerja dengan tuntutan situasi dan waktu yang tinggi dia tetap merasa memiliki kualitas hidup yang baik.
\end{abstract}

Kata Kunci: kualitas hidup, grit, persepsi dukungan organisasi, karakteristik pekerjaan. 


\section{PENDAHULUAN}

Pertumbuhan teknologi informasi dan komunikasi di Indonesia berlangsung pesat. Hal ini ditandai dengan semakin banyaknya perusahaan informasi dan telekomunikasi (IT). Perusahaanperusahaan ini diantaranya adalah perusahaan yang menyediakan produk atau jasa IT bagi para pelanggannya. Perusahaan-perusahaan ini memiliki kesepakatan mengenai tingkat layanan yang dijanjikan akan diberikan kepada para pelanggan. Kesepakatan ini dikenal dengan istilah Perjanjian Tingkat Layanan atau Service Level Agreement (SLA). Service Level Agreement (SLA) adalah kontrak layanan antara penyedia layanan dan pelanggan. SLA memberikan aspek spesifik dan terukur terkait dengan penawaran layanan. Sebagai contoh, SLA sering dimasukkan dalam perjanjian yang ditandatangani antara penyedia layanan Internet (ISP) dan pelanggan.

Bagi perusahaan penyedia produk dan jasa IT, SLA menjadi hal kritis karena merupakan jaminan akan layanan yang diberikan kepada pelanggan. Hal ini berarti SLA juga menjadi target yang harus dipenuhi oleh karyawan. Tidak jarang dalam rangka memenuhi target tersebut karyawan harus menyelesaikan tugas berupa mengatasi permasalahan (trouble shoot) meski sudah diluar jam kerja. Namun berkat perkembangan teknologi komunikasi dan gawai pintar, telah memungkinkan seseorang untuk selalu terhubung dengan pekerjaannya kapanpun dan dimanapun (Kossek \& Lautsch dalam Derks, van Duin, Tims, \& Bakker, 2015). Kemajuan teknologi membuat seseorang sangat mungkin untuk selalu dapat dihubungi dan mengembangkan mentalitas selalu bersedia untuk bekerja (Middleton dalam Park, Fritz, \& Jex, 2011).

Penggunaan gawai pintar dan tersedianya koneksi internet sangat memungkinkan bagi seseorang untuk dapat selalu terhubung dengan pekerjaannya. Namun dengan kondisi "selalu terhubung" pekerjaan ini, membuat karyawan kesulitan untuk menemukan waktu guna secara mental melepaskan diri dari pekerjaan saat tidak bekerja. Beberapa penelitian sebelumnya dari hasil studi dengan metode buku harian (diary) menunjukkan bahwa terlepas dari pekerjaan berhubungan dengan rendahnya fatigue saat waktu tidur (Sonnentag \& Bayer dalam dalam Park et al., 2011) dan saat keesokan harinya (Sonnentag et al. dalam Park et al., 2011). Selain itu, penelitian cross-sectional telah menemukan bahwa terlepas dari pekerjaan selama waktu senggang secara positif terkait dengan kepuasan hidup (Fritz, Yankelevich, Zarubin \& Barger dalam Park et al., 2011).

Selalu terhubung dengan pekerjaan juga mempengaruhi kualitas hidup seseorang diantaranya dengan terganggunya waktu istirahat dan keseimbangan antara kehidupan pribadi dengan pekerjaan yang mana kedua hal ini merupakan bagian dari kualitas hidup secara keseluruhan. Bagi organisasi, apabila karyawannya memiliki kualitas kehidupan kerja yang rendah, maka hal ini akan mempengaruhi turnover intention (Rostiana, 2017). Sirgy (2012) menyebutkan beberapa hal yang menjadi prediktor kualitas hidup yaitu lingkungan kerja yang baik, karakter individu itu sendiri dan perilaku kerja. Lingkungan kerja yang baik diantaranya dirasakan karyawan melalui Persepsi dukungan organisasi yang menjadi salah satu faktor eksternal yang membantu karena menunjukkan adanya komitmen dari organisasi kepada karyawannya. Persepsi dukungan organisasi menunjukkan perlakuan yang baik dari organisasi. Berdasarkan norma timbal balik dari karyawan untuk peduli terhadap organisasi mereka dan memperlakukan organisasi mereka dengan baik sebagai pengembaliannya (Eisenberger et al. dalam Ristig, 2009).

Selain faktor eksternal, adanya faktor dari dalam diri seseorang seperti Grit yang menunjukkan kegigihan akan membantu seseorang dalam mencapai tujuannya. Grit adalah kombinasi dari ketekunan dan semangat untuk tujuan jangka panjang. Grit memerlukan bekerja keras terhadap tantangan, mempertahankan upaya dan minat selama bertahun-tahun meskipun kegagalan, kesulitan, dan kemajuan terasa lambat (A. L. Duckworth, Peterson, Matthews, \& Kelly, 2007).

Pekerjaan itu sendiri dan perilaku yang ditunjukkan terhadap pekerjaan juga menjadi salah 
Kemajuan teknologi memungkinkan seseorang untuk dapat mengakses pekerjaan dari manapun. Hal ini dapat menjadi keuntungan karena adanya fleksibilitas dalam bekerja. Namun disaat yang sama juga memungkinkan pekerja menghadapi stress kerja dimanapun. Situasi kerja yang seperti ini sangat mungkin mempengaruhi kualitas hidup para pekerja di bidang produk atau jasa IT. Namun, dengan merujuk pada yang telah disampaikan Sirgy (2012) sebelumnya mengenai prediktor kualitas hidup, maka peneliti menyusun hipotesis penelitian yaitu grit, sebagai bagian dari faktor individu, mempengaruhi kualitas hidup (H1), dukungan organisasi, sebagai bagian dari lingkungan kerja, mempengaruhi kualitas hidup (H2) dan karakteristik pekerjaan, sebagai bagian dari perilaku kerja, mempengaruhi kualitas hidup (H3).

\section{Tinjauan Pustaka}

Kualitas Hidup

Konsep kualitas hidup secara luas mencakup bagaimana seseorang mengukur "kebaikan" dari berbagai aspek kehidupan mereka. Evaluasi ini termasuk reaksi emosional seseorang terhadap kejadian kehidupan, disposisi, kepuasan hidup dan kepuasan, dengan pekerjaan dan hubungan pribadi (Diener, Suh, Lucas \& Smith dalam Theofilou, 2013). Pada beberapa literatur, istilah kualitas hidup sering digantikan dengan istilah well-being. Baik kualitas hidup maupun well-being sama-sama memiliki komponen objektif, yaitu, komponen eksternal untuk individu dan dapat diukur oleh orang lain dan komponen subjektif, yaitu, penilaian pribadi atas kehidupan sendiri atau aspek-aspek kehidupan tertentu menggunakan ukuran kepuasan, kebahagiaan, atau skala penilaian diri lainnya (Campbell et al. dalam Theofilou, 2013).

Pada beberapa literatur, istilah kualitas hidup sering digantikan dengan istilah well-being. Baik kualitas hidup maupun well-being sama-sama memiliki komponen objektif, yaitu, komponen eksternal untuk individu dan dapat diukur oleh orang lain dan komponen subjektif, yaitu, penilaian pribadi atas kehidupan sendiri atau aspek-aspek kehidupan tertentu menggunakan ukuran kepuasan, kebahagiaan, atau skala penilaian diri lainnya (Campbell et al. dalam Theofilou, 2013).

Domain dan aspek-aspek pendukungnya yang pertama adalah Domain Fisik. Domain fisik secara garis besar menjelaskan aspek-aspek yang berhubungan dengan kesehatan fisik. Domain yang kedua adalah domain psikologis, yaitu domain-domain yang terkait dengan kondisi psikologis seseorang yang mempengaruhi kualitas hidupnya. Domain yang ketiga adalah domain tingkat kemandirian, yaitu domain yang berkaitan dengan kemudahan dan kebebasan seseorang untuk melakukan kegiatannya sehari-hari. Domain yang keempat adalah domain hubungan social, yaitu domain domain yang terdiri dari aspek Personal relationship, Social support dan Sexual activity. Aspek Social support meneliti seberapa besar seseorang merasakan komitmen, persetujuan, dan tersedianya bantuan praktis dari keluarga dan teman. Domain kelima adalah domain lingkungan. Lingkungan yang dimaksud pada domain ini adalah lingkungan secara fisik dan sosial. Domain keenam adalah domain keyakinan spiritual. Domain ini memeriksa keyakinan pribadi seseorang dan bagaimana hal ini mempengaruhi kualitas hidup.

\section{$\underline{\text { Grit }}$}

Grit adalah kecenderungan untuk mempertahankan ketekunan dan semangat untuk mencapai tujuan jangka panjang (A. L. Duckworth et al., 2007). Grit memampukan seseorang untuk bekerja keras dalam menghadapi tantangan, mempertahankan usaha dan minat sepanjang tahun meskipun kegagalan, kesulitan terjadi atau tanpa adanya kemajuan. Menurut Duckworth (2007), grit memiliki dua aspek, yaitu (1) Konsistensi minat (Passion). Konsistensi minat adalah seberapa konsisten usaha seseorang untuk menuju suatu arah. Konsistensi minat dapat dilihat dari minat dan tujuan seseorang yang tidak mudah berubah, tidak mudah dialihkan dengan ide atau minat atau tujuan lain dan tetap pada tujuannya semula. Memiliki minat juga berarti berupaya mencapai tujuan dan tidak meninggalkan tugas hanya karena menghadapi perubahan atau mencari sesuatu yang baru (Duckworth, 2017). (2) Ketekunan usaha (perseverance). Ketekunan usaha adalah seberapa keras seseorang berusaha untuk mencapai tujuan serta berapa lama seseorang dapat mempertahankan usahanya. Ketekunan dapat dilihat dari perilaku yang rajin atau pekerja keras, bertahan dalam menghadapi rintangan dan tantangan. Ketekunan juga berarti memiliki

Jurnal Manajeme dan Organisasi (JMO), Vol. 12 No. 2 , Agustus 2021, Hal. 89-98 
tekad untuk tetap pada arah tujuan yang telah ditetapkan sebelumnya, tidak meninggalkan tugas meski menghadapi tantangan serta memiliki keuletan (Duckworth, 2017).

Duckworth et al. (2007) menemukan bahwa terdapat faktor-faktor yang memiliki peranan terhadap grit, yaitu : (a) Usia; (b) Pendidikan; (c) Conscientiousness. Berdasarkan penelitian yang dilakukan oleh Duckworth et al. (2007), usia ditemukan menjadi salah satu faktor penentu grit. Individu yang usianya lebih dewasa ditemukan memiliki grit yang lebih tinggi jika dibandingkan dengan individu yang usianya lebih muda. Duckworth et al. (2007) berasumsi bahwa grit berkembang sejalan dengan usia mengingat pembelajaran yang diperoleh individu melalui pengalaman bahwa menyerah dari rencana yang sudah ditetapkan, mengganti tujuan terus menerus dan mengulang segala sesuatu dari awal lagi bukanlah stategi yang baik dalam mencapai kesuksesan.

Demikian juga dengan pendidikan. Menurut Duckworth et al. (2007), individu yang berpendidikan memiliki grit yang lebih tinggi daripada individu yang pendidikannya lebih rendah walaupun kedua individu tersebut memiliki usia yang sama. Selain itu, grit juga memiliki hubungan positif yang signifikan dengan conscientiousness lebih daripada neuroticism, agreeableness, extraversion dan openness to experience (Duckworth et al., 2007). Meskipun demikian, penekanan kedua konstruk terhadap staminalah yang membuat keduanya dibedakan menjadi 2 konstruk yang berbeda. Individu yang memiliki grit yang tinggi tetap mengejar tujuan jangka panjangnya walaupun tidak mendapatkan feedback yang positif (Duckworth et al. 2007).

\section{Persepsi Dukungan Organisasi}

Persepsi dukungan organisasi atau Perceived Organizational Support (POS) didefinisikan sebagai sejauh mana karyawan melihat bahwa kontribusi mereka dihargai oleh organisasi dan bahwa perusahaan peduli akan kesejahteraan mereka (Eisenberger, Fasolo \& Davis-LaMastro dalam Stamper \& Johlke, 2003). Menurut Teori dukungan organisasi atau organizational support theory, perkembangan persepsi dukungan organisasi didorong oleh kecenderungan karyawan untuk melihat karakteristik organisasi seperti layaknya manusia (Eisenberger et al. dalam Rhoades \& Eisenberger, 2002). Tindakan yang dilakukan oleh perwakilan organisasi sering kali dipandang sebagai tindakan dari organisasi itu sendiri ketimbang sebagai tindakan oleh perorangan.

Dukungan organisasional dipengaruhi oleh interaksi seseorang dengan organisasi dimana organisasi tersebut memberikan pujian, dukungan dan persetujuan. Sedangkan Blau (dalam Rhoades et al., 2001) menyatakan bahwa perceived organizational support dipengaruhi oleh frekuensi, keekstriman, dan usaha pemberian pujian dan penghargaan, serta rewards lainnya seperti gaji, penilaian kinerja, job enrichment, dan pengaruh kebijakan organisasi.

Armeli et al., (dalam Eisenberger et al., 2002) mengatakan bahwa dukungan organisasi dapat membantu memenuhi kebutuhan-kebutuhan sosial dan emosional karyawan, yang pada akhirnya menciptakan kewajiban karyawan untuk membalas jasa kepada organisasi. Tingginya level dukungan organisasi akan menciptakan perasaan untuk memenuhi kewajiban karyawan bukan hanya merasa bahwa mereka harus memiliki komitmen kepada organisasi, melainkan juga merasa berkewajiban untuk member balas jasa atas komitmen yang diberikan organisasi dengan menunjukkan perilaku yang mendukung tujuan organisasi.

\section{Karakteristik Pekerjaan}

Teori karakteristik pekerjaan dikembangkan oleh Hackman dan Oldham dengan ide dasar bahwa tugas itu sendiri merupakan kunci yang dapat memotivasi karyawan. Pekerjaan yang membosankan dan monoton menghambat motivasi untuk bekerja dengan baik. Sebaliknya, pekerjaan yang menantang meningkatkan motivasi. Menurut Hackman \& Oldham (dalam Ivancevich \& Konopaske, 2013) ada 5 karakteristik pekerjaan yang dapat memotivasi seseorang. Karakteristik yang pertama adalah keberagaman kemampuan (skill variety). Skill variety adalah sejauh mana pekerjaan membutuhkan berbagai kegiatan yang berbeda agar dapat diselesaikan, yang melibatkan penggunaan sejumlah keterampilan dan bakat yang berbeda dari seseorang (Hackman \& Oldham, dalam Ivancevich \& Konopaske, 2013). Menurut Judge (dalam Haryanto, 
R \& Suyasa, 2007), skill variety adalah suatu tingkat dimana pekerja dimungkinkan untuk melakukan tugas-tugas yang beragam.

Karakteristik pekerjaan yang kedua adalah identitas tugas (task identity). Task identity adalah sejauh mana pekerjaan itu membutuhkan penyelesaian secara keseluruhan, yaitu melakukan pekerjaan dari awal hingga akhir (Hackman \& Oldham, dalam Ivancevich \& Konopaske, 2013). Hal ini berarti melakukan pekerjaan sebagai suatu keseluruhan proses, bukan hanya sekedar bagian per bagian. Karyawan cenderung lebih merasa pekerjaannya berarti ketika mereka dapat menyelesaikan dan melihat hasil akhir pekerjaan yang mereka lakukan. Task identity menunjukkan bahwa suatu pekerjaan memiliki semacam sub bagian yang perlu diselesaikan agar pekerjaan keseluruhan dapat terselesaikan (Haryanto \& Suyasa, 2007).

Karakteristik pekerjaan yang ketiga adalah signifikansi tugas (task significance). Task significance adalah sejauh mana pekerjaan itu memiliki dampak besar pada kehidupan orang lain, baik orang-orang yang berada dalam organisasi maupun orang-orang lain secara umum (Hackman \& Oldham, dalam Ivancevich \& Konopaske, 2013). Bagi banyak orang, pekerjaan lebih bermakna jika bisa membantu meningkatkan kesejahteraan orang lain (bukan hanya dirinya sendiri), baik secara fisik, psikologis, atau emosional. Mengetahui bahwa pekerjaan mereka, dan kinerja mereka, memiliki kemampuan untuk memiliki dampak positif pada orang lain akan memotivasi mereka lebih lanjut untuk menjadi lebih baik. Menurut Robbins dalam Haryanto \& Suyasa (2007), task significance adalah tingkatan dimana pekerjaan secara mendasar berpengaruh pada kehidupan dan pekerjaan orang lain.

Karakteristik pekerjaan yang keempat adalah otonomi (Autonomy). Menurut Hackman \& Oldham dalam Ivancevich \& Konopaske (2013), Autonomy adalah sejauh mana suatu pekerjaan memberikan kebebasan, dan kemandirian kepada individu dalam menjadwalkan pekerjaan dan dalam menentukan prosedur yang akan digunakan dalam melaksanakannya, atau suatu tingkatan dimana pekerja memiliki kontrol dan keleluasaan untuk mengatur pekerjaan mereka (Judge dalam Haryanto \& Suyasa, 2007). Kebebasan dalam melakukan pekerjaan tidak hanya terjadi pada karyawan di level manajerial, melainkan dari seluruh level. Karena karyawan akan memiliki rasa tanggung jawab yang kuat jika mereka dibiarkan dalam melakukan tugas mereka dengan menggunakan upaya dan inisiatif mereka sendiri, dan mereka diizinkan untuk membuat keputusan.

Karakteristik pekerjaan yang terakhir adalah umpan balik (feedback). Menurut Hackman \& Oldham dalam Ivancevich \& Konopaske (2013), feedback adalah sejauh mana pekerjaan menyediakan umpan balik atau informasi yang jelas mengenai efektivitas kinerja yang ditunjukkan. Sedangkan menurut Judge dalam Haryanto dan Suyasa (2007), feedback adalah suatu tingkatan dimana pekerjaan memberikan umpan balik tentang bagaimana pekerja mengerjakan pekerjaannya. Feedback menunjukkan bahwa suatu hasil pekerjaan memberikan informasi mengenai cara pengerjaan dan efektivitas kerja.

\section{METODE PENELITIAN}

Metode penarikan sampel pada penelitian ini dilakukan dengan menggunakan metode nonprobability sampling dengan teknik metode purposive sampling, yaitu memilih sekelompok partisipan berdasarkan atas kriteria-kriteria tertentu yang telah ditentukan sebelumnya (Sugiyono, 2013). Partisipan penelitian ini adalah karyawan IT baik di industri jasa IT maupun produk IT yang memiliki standar layanan dalam melakukan pekerjaannya. Pengambilan data penelitian ini dengan menggunakan dokumen online sehingga memudahkan untuk diakses oleh responden yang berada dilokasi yang berjauhan. Pengambilan data dilakukan dua kali dengan jeda waktu 1 sampai 3 minggu antara studi kesatu dan kedua. Kuesioner studi kesatu diisi oleh 208 orang partisipan tapi terdapat 9 orang partisipan yang tidak sesuai dengan kriteria partisipan yang dibutuhkan dalam penelitian ini dikarenakan tidak bekerja sebagai karyawan IT, melainkan sebagai sales, marketing, ibu rumah tangga dan mahasiswa system informatika. Sedangkan kuesioner studi kedua diisi oleh 137 orang partisipan tapi 9 orang yang tadi tidak sesuai kriteria partisipan kembali tidak dapat diikutsertakan. Dengan demikian, terdapat 128 orang partisipan yang sesuai dengan 
kriteria serta mengikuti studi kesatu dan kedua. Mayoritas responden pada studi 1 dan 2 berjenis kelamin laki-laki (170 orang pada studi 1 atau 85 persen dan 98 orang atau 77 persen pada studi 2).

Kualitas hidup diukur menggunakan alat ukur yang dikembangkan oleh World Health Organization atau WHO (1998) yang diadaptasi ke dalam Bahasa Indonesia. Jumlah item sebanyak 37 butir yang terdiri dari 6 dimensi yaitu dimensi fisik, psikologis, tingkat kemandirian, hubungan sosial, lingkungan dan keyakinan spiritual. Contoh butir dimensi fisik adalah "Seberapa besar energi/tenaga yang Anda miliki, untuk melakukan kegiatan sehari-hari?". Grit diukur menggunakan Grit Scale yang dikembangkan oleh Angela Duckworth yang telah diadaptasi ke dalam Bahasa Indonesia. Jumlah item dalam Grit sebanyak 12 butir. Contoh butir dimensi konsistensi minat adalah "Ide/proyek/pekerjaan baru terkadang membuat saya tergoda untuk beralih dari tujuan/proyek/pekerjaan sebelumnya (yang telah saya rencanakan)".

Persepsi dukungan organisasi diukur menggunakan alat ukur yang dikembangkan oleh Eisenberger dan telah diadaptasi ke Bahasa Indonesia. Jumlah item 16 butir. Contoh butir item adalah "Perusahaan peduli terhadap kepuasan kerja saya". Karakteristik pekerjaan diukur menggunakan alat ukur yang dikembangkan oleh Hackman dan Oldham dan telah diadaptasi ke Bahasa Indonesia, menyesuaikan dengan kebutuhan penelitian. Jumlah item 21 butir yang mengandung 5 dimensi karakteristik pekerjaan. Contoh butir item dimensi otonomi adalah "Saya memiliki kebebasan dalam melakukan pekerjaan saya".

Analisa data penelitian dilakukan dengan analisis structural equation model (SEM) dengan menggunakan software Lisrel 8.70. SEM adalah metode analisis multivariate yang dapat digunakan untuk menggambarkan keterkaitan hubungan linier secara simultan antara variabel pengamatan (indicator) dan variabel yang tidak dapat diukur secara langsung (variabel laten) (Prihandini \& Sunaryo, 2011). SEM merupakan suatu teknik analisis multivariate yang digunakan untuk menganalisis hubungan antar variabel yang lebih kompleks dibandingkan dengan analisis regresi berganda dan analisis faktor.

\section{HASIL DAN PEMBAHASAN}

Pengolahan data deskriptif penelitian ini dilakukan dengan menggunakan SPSS sedangkan uji hipotesis dilakukan dengan menggunakan SEM dari Lisrel.

Tabel 1. Rerata dan Standar Deviasi Studi 1 dan 2

\begin{tabular}{lcccc}
\hline & \multicolumn{2}{c}{ Studi 1 } & \multicolumn{2}{c}{ Studi 2 } \\
& Mean & Std. Dev & Mean & Std. Dev \\
\hline Kualitas Hidup & 3,90 & 0,40 & 3,97 & 0,45 \\
Fisik & 3,93 & 0,47 & 3,92 & 0,52 \\
Kemandirian & 3,78 & 0,68 & 3,77 & 0,75 \\
Lingkungan & 3,89 & 0,47 & 3,96 & 0,49 \\
Psikologis & 3,88 & 0,50 & 3,90 & 0,57 \\
Sosial & 3,71 & 0,54 & 3,87 & 0,57 \\
Spiritual & 4,09 & 0,58 & 4,32 & 0,53 \\
Grit & 3,57 & 0,52 & 3,44 & 0,46 \\
& 3,43 & 0,62 & 3,28 & 0,53 \\
Passion & 3,70 & 0,55 & 3,60 & 0,53 \\
Perseverance & 4,18 & 0,78 & 4,08 & 0,82 \\
Persepsi dukungan organisasi & 4,79 & 0,59 & 4,83 & 0,65 \\
Oakteristik pekerjaan & 4,54 & 0,92 & 4,41 & 0,96 \\
Otonomi & 4,45 & 0,75 & 4,52 & 0,85 \\
Umpan balik & 4,78 & 0,71 & 4,84 & 0,76 \\
Variasi keterampilan & 4,81 & 0,70 & 4,88 & 0,74 \\
Identitas tugas & 5,09 & 0,70 & 5,17 & 0,73 \\
signifikansi tugas & & & &
\end{tabular}

Kuesioner kualitas hidup menggunakan skala likert dengan kontinum nilai minimal 1 hingga maksimal 5. Dengan demikian nilai mediannya adalah 3. Pada studi 1 maupun studi 2 diperoleh hasil mean lebih tinggi dari nilai tengah. Hal tersebut berarti karyawan IT memiliki Kualitas Hidup yang cukup tinggi. Masing-masing dimensi kualitas hidup pada studi kesatu dan 
kedua juga memiliki nilai rata-rata diatas nilai tengah. Pada studi kesatu, nilai rata-rata dari tiap dimensi adalah 3,93 (fisik), 3,78 (kemandirian), 3,89 (lingkungan), 3,88 (psikologis), 3,71 (sosial) dan 4,09 (spiritual). Pada studi kedua, nilai rata-rata dari tiap dimensi adalah 3,92 (fisik), 3,77 (kemandirian), 3,96 (lingkungan), 3,90 (psikologis), 3,87 (sosial) dan 4,32 (spiritual). Hal ini berarti para karyawan IT memiliki kualitas hidup yang baik pada setiap aspek. Item kuesioner grit menggunakan skala likert dengan kontinum nilai minimal 1 hingga maksimal 5. Dengan demikian nilai mediannya adalah 3. Pada masing-masing dimensi grit di studi kesatu dan kedua juga memiliki nilai rata-rata diatas nilai tengah. Pada studi kesatu, nilai rata-rata dimensi passion adalah 3,43 dan dimensi perseverance adalah 3,70. Sedangkan pada studi kedua, nilai rata-rata dimensi passion adalah 3,28 dan dimensi perseverance adalah 3,60. Hal ini berarti para karyawan IT memiliki grit yang baik.

Item kuesioner persepsi dukungan organisasi menggunakan skala likert dengan kontinum nilai minimal 1 hingga maksimal 6. Dengan demikian nilai mediannya adalah 3,5. Pada studi kesatu, diperoleh nilai rata-rata atau mean dari persepsi dukungan organisasi adalah sebesar 4,18 dengan standar deviasi sebesar 0,78. Sedangkan pada studi kedua diperoleh nilai rata-rata atau mean persepsi dukungan organisasi sebesar 4,08 dengan standar deviasi sebesar 0,82. Pada studi kesatu dan kedua, nilai rata-rata persepsi dukungan organisasi berada diatas nilai tengah. Hal tersebut berarti karyawan IT mempersepsikan mendapat dukungan yang baik dari organisasi.

Item kuesioner karakteristik pekerjaan menggunakan skala likert dengan kontinum nilai minimal 1 hingga maksimal 6. Dengan demikian nilai mediannya adalah 3,5. Pada studi kesatu, diperoleh nilai rata-rata atau mean karakteristik pekerjaan sebesar 4,79 dengan standar deviasi sebesar 0,59. Sedangkan pada studi kedua diperoleh nilai rata-rata atau mean karakteristik pekerjaan sebesar 4,83 dengan standar deviasi sebesar 0,65. Pada studi kesatu dan kedua, nilai rata-rata karakteristik pekerjaan berada cukup jauh diatas nilai tengah. Hal tersebut berarti karyawan IT menilai pekerjaannya memiliki aspek internal yang baik.

Sebelum dilakukan uji hipotesis, dilakukan uji beda rerata dengan pengukuran statistik non parametrik, yaitu Wilcoxon Signed Rank Test karena data yang diperoleh tidak normal. Tujuan dari pengukuran ini adalah untuk memastikan hasil studi 1 dan 2 adalah sama atau tidak berbeda. Melalui hasil perhitungan perbandingan rerata diperoleh hasil sebagai berikut:

Tabel 2. Uji Beda Studi 1 dan 2

\begin{tabular}{lcccc}
\hline & $\begin{array}{c}\text { Kualitas } \\
\text { hidup 1 - } \\
\text { Kualitas } \\
\text { hidup 2 }\end{array}$ & Grit 1 - & POS 1 - & $\begin{array}{c}\text { Karakteristik } \\
\text { Pekerjaan 1 - } \\
\text { Karakteristik } \\
\text { Pekerjaan 2 }\end{array}$ \\
\hline Z & -.874 & -1.332 & POS 2 & -.319 \\
Asymp. Sig. (2-tailed) & .382 & .183 & .749 & .539 \\
\hline
\end{tabular}

Berdasarkan perhitungan diatas, diketahui Asymp.Sig. (2-tailed) untuk kualitas hidup bernilai .382, untuk grit sebesar .183, untuk persepsi dukungan organisasi sebesar .749 dan untuk karakteristik pekerjaan sebesar .539. Keempat hasil tersebut bernilai lebih besar dari 0.05 , sehingga dapat disimpulkan bahwa tidak terdapat perbedaan yang signifikan antara pengukuran kualitas hidup, grit, persepsi dukungan organisasi dan karakteristik pekerjaan pada studi 1 dan studi 2. Hal ini berarti hasil studi kesatu tidak berbeda dari hasil studi kedua atau dapat dianggap sama.

Tabel 3. Goodness of Fit Persamaan Struktural

\begin{tabular}{lccc}
\hline Kriteria & Nilai batas & Hasil & Kesimpulan \\
\hline$\chi^{2}($ Chi Square) & $\leq \chi^{2}$ tabel $(84,82)$ & 77,53 & Fit \\
Significance probability $(p)$ & $\geq 0,05$ & 0,13713 & Fit \\
GFI & $\geq 0,90$ & 0,93 & Fit \\
CFI & $\geq 0,90$ & 0,99 & Fit \\
NNFI & $\geq 0,90$ & 0,99 & Fit \\
RMSEA & $\leq 0,08$ & 0,039 & Fit \\
RMR & $\leq 0,05$ & 0,045 & Fit \\
\hline
\end{tabular}


Merujuk pada tabel diatas, terlihat bahwa beberapa persyaratan dalam menilai kelayakan suatu model terpenuhi. Dengan demikian, model persamaan structural ini dapat dikatakan fit. Setelah model dinyatakan fit, maka dapat dilakukan uji hipotesis dari penelitian ini. berikut:

Uji hipotesis yang dilakukan dengan menggunakan Lisrel dan diperoleh hasil sebagai

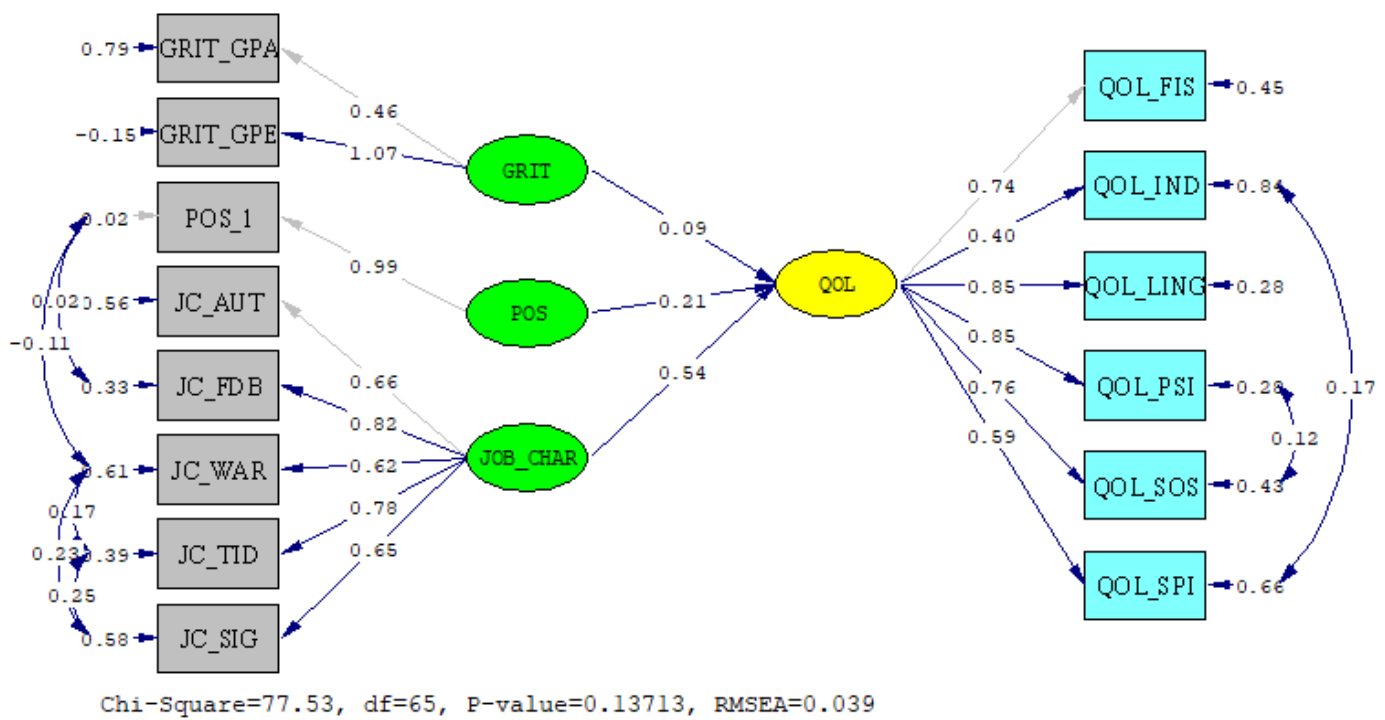

Gambar 1. Pengujian Pengaruh Grit, Persepsi Dukungan Organisasi dan Karakteristik Pekerjaan terhadap Kualitas Hidup (Standardized)

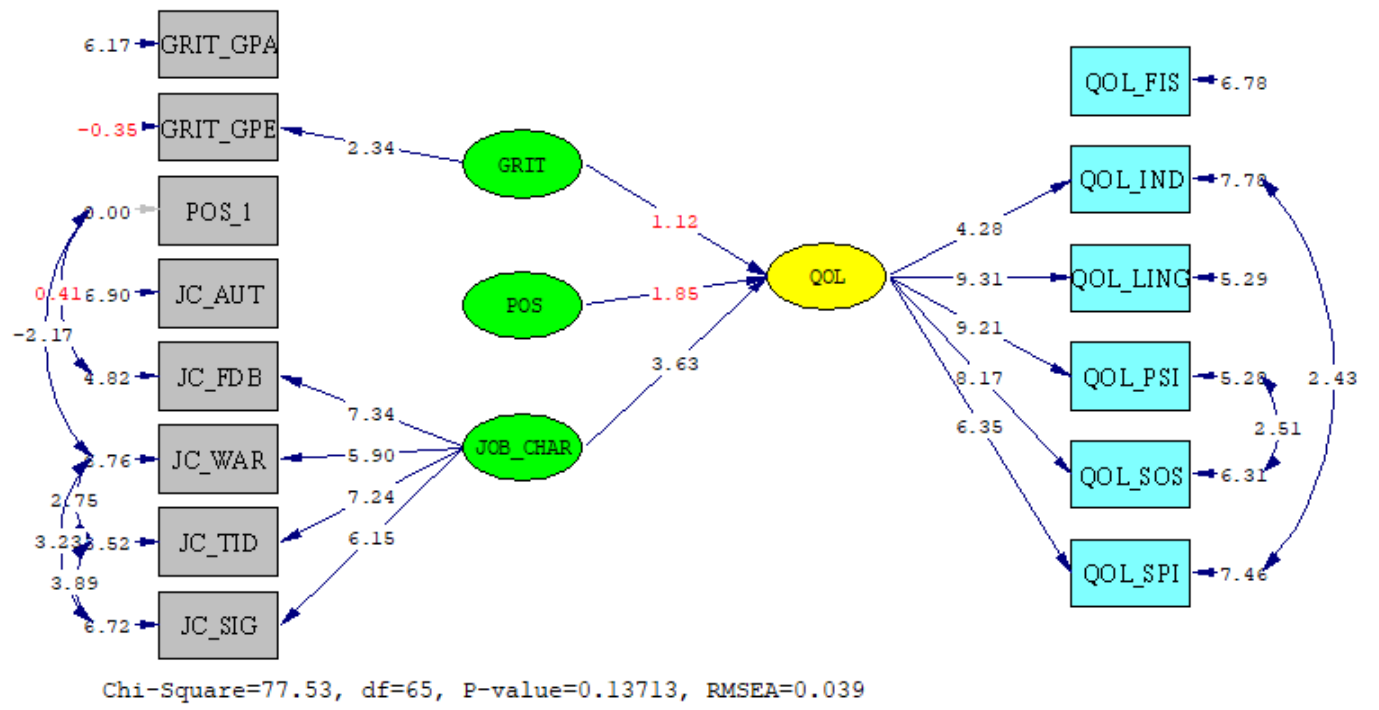

Gambar 2. Pengujian Pengaruh Grit, Persepsi Dukungan Organisasi dan Karakteristik Pekerjaan terhadap Kualitas Hidup (t-values)

Berdasarkan gambar 1 diatas terlihat bahwa grit memiliki angka loading factor sebesar 0,09 dan persepsi dukungan organisasi memiliki angka loading factor sebesar 0,21. Sedangkan Karakteristik Pekerjaan memiliki angka loading factor sebesar 0,64. Selain itu berdasarkan gambar 2, peneliti mendapatkan nilai $t$-values grit sebesar 1,12 dan nilai t-values persepsi dukungan organisasi sebesar 1,85 sedangkan nilai t-values karakteristik tugas adalah sebesar 3,63.

Pengujian dilakukan terhadap tiga hipotesis yang diajukan. Pengujian hipotesis dilakukan dengna menggunakan nilai t-values pada tingkat signifikansi 0,05. Menurut Haryono (2017), apabila nilai t-values $\geq 1,96$ maka $\mathrm{H} 0$ ditolak atau berarti hipotesis penelitian diterima. Dengan 
demikian, H1 yang berbunyi "Grit berpengaruh terhadap kualitas hidup" ditolak dan H2 yang berbunyi "Pesepsi dukungan organisasi berpengaruh terhadap kualitas hidup" ditolak. Sedangkan H3 yang berbunyi "Karakteristik pekerjaan berpengaruh dengan kualitas hidup" diterima.

Menurut Hackman \& Oldham dalam Ivancevich \& Konopaske (2013), kelima karakteristik pekerjaan akan mempengaruhi kondisi psikologis yang penting bagi karyawan, salah satunya adalah kebermaknaan pekerjaan (meaningfulness of work). Karyawan perlu merasa bahwa pekerjaan yang mereka lakukan adalah suatu hal yang memiliki makna. Hult, Pietilä, \& Saaranen (2020) menegaskan bahwa kebermaknaan mempengaruhi kualitas hidup. Pada orang tidak bekerja pengaruhnya sedikit lebih rendah dari orang yang memiliki pekerjaan (Hult, Pietilä, \& Saaranen, 2019).

Dimensi umpan balik menjadi faktor yang paling berperan dalam karakteristik pekerjaan. Hal ini menunjukkan karyawan IT mempersepsikan bahwa dalam melakukan pekerjaannya mereka mendapatkan informasi yang jelas mengenai tugas dan efektifitas pekerjaan yang dilakukan. Selain itu, identitas tugas juga menjadi faktor yang berperan dalam karakteristik pekerjaan. Hal ini berarti karyawan IT mempersepsikan pekerjaan yang dilakukannya merupakan makna dan bagian dari suatu rangkaian proses yang lebih besar.

\section{KESIMPULAN}

Berdasarkan penelitian dan analisis yang telah dilakukan tentang pengaruh grit, persepsi dukungan organisasi dan karakteristik pekerjaan terhadap kualitas hidup pada karyawan IT, maka diperoleh hasil bahwa Kualitas hidup pada karyawan IT tidak pengaruhi oleh grit dan persepsi dukungan organisasi. Kualitas hidup pada karyawan IT dipengaruhi oleh karakteristik pekerjaan khususnya yang berkaitan dengan umpan balik dan identitas tugas.

Jika melihat mayoritas partisipan penelitian berjenis kelamin laki-laki yang berada di rentang usia dewasa awal, maka dapat dipahami jika pekerjaan menjadi bagian penting dari kehidupan mereka. Dengan jumlah waktu yang dihabiskan untuk melakukan pekerjaan kurang lebih sepertiga dari jumlah waktu dalam satu hari, maka hal-hal yang berkaitan dengan pekerjaan mendapat perhatian yang cenderung tinggi.

Dimensi umpan balik menjadi faktor yang paling berperan dalam karakteristik pekerjaan. Hal ini menunjukkan karyawan IT mempersepsikan bahwa dalam melakukan pekerjaannya mereka mendapatkan informasi yang jelas mengenai tugas dan efektifitas pekerjaan yang dilakukan. Selain itu, identitas tugas juga menjadi faktor yang berperan dalam karakteristik pekerjaan. Hal ini berarti karyawan IT mempersepsikan pekerjaan yang dilakukannya merupakan bagian dari suatu rangkaian proses yang lebih besar.

\section{DAFTAR PUSTAKA}

Derks, D., van Duin, D., Tims, M., \& Bakker, A. B. (2015). Smartphone use and work-home interference: The moderating role of social norms and employee work engagement. Journal of Occupational and Organizational Psychology, 88(1), 155-177. https://doi.org/10.1111/joop.12083.

Duckworth, A., \& Gross, J. J. (2014). Self-Control and Grit: Related but Separable Determinants of Success. Current Directions in Psychological Science, 23(5), 319-325. https://doi.org/10.1177/0963721414541462.

Duckworth, A. L. (2017). Grit: The Power of Passion and Perseverance. Scribner.

Duckworth, A. L., Peterson, C., Matthews, M. D., \& Kelly, D. R. (2007). Grit: Perseverance and Passion for Long-Term Goals. Journal of Personality and Social Psychology, 92(6), 10871101. https://doi.org/10.1037/0022-3514.92.6.1087.

Faturochman. (1997). The Job Characteristics Theory: A review. Buletin Psikologi, v(2).

Haryono, Siswoyo (2017). Metode SEM untuk Penelitian Manajemen AMOS Lisrel PLS. Jakarta :Luxima

Haryanto, R \& Suyasa, T. Y. S. (2007). Persepsi terhadap job characteristic model, psychological 
well-being, dan performance (studi pada karyawan PT. X). Phronesis Jurnal Ilmiah Psikologi Industri Dan Organisasi, 9, 67-92.

Hult, M., Pietilä, A.-M., \& Saaranen, T. (2019). Improving employment opportunities of the unemployed by health and work ability promotion in Finland. Health Promotion International, 35(3), 518-526. https://doi.org/10.1093/heapro/daz048.

Hult, M., Pietilä, AM. \& Saaranen, T. (2020). The Factors Predicting Quality of Life Among Unemployed Adults: A Model Based on Salutogenic Approach. Social Indicator Result, 152, 1197-1211. https://doi.org/10.1007/s11205-020-02470-0.

Hurlock, E. B. (2011). Psikologi Perkembangan : Suatu Pendekatan Sepanjang Rentang Kehidupan. Jakarta: Erlangga

Ivancevich, J. M. \& Konopaske, R. (2013). Human Resource Management $12^{\text {th }}$ edition. New York : McGraw-Hill/Irwin.

Park, Y. A., Fritz, C., \& Jex, S. M. (2011). Relationships Between Work-Home Segmentation and Psychological Detachment From Work: The Role of Communication Technology Use at Home. Journal of Occupational Health Psychology, 16(4), 457-467. https://doi.org/10.1037/a0023594.

Prihandini, T. I \& Sunaryo, S. (2011). Structural Equation Modelling (SEM) dengan Model Struktural Regresi Spasial. Makalah dipresentasikan pada Seminar Nasional Statistika, Universitas Diponegoro Semarang, 21 Mei 2011.

Rao, J., \& Chandraiah, K. (2012). Occupational stress, mental health and coping among information technology professionals. Indian Journal of Occupational and Environmental Medicine, 16(1), 22. https://doi.org/10.4103/0019-5278.99686.

Rhoades, L., \& Eisenberger, R. (2002). Perceived Organizational Support: A Review of the Literature. Journal of Applied Psychology, 87(4), 698-714. https://doi.org/10.1037//00219010.87.4.698.

Ristig, K. (2009). The impact of perceived organizational support and trustworthiness on trust. Management Research News, 32(7), 659-668.

Rostiana, R. (2017). The quality of work life influence to turnover intention with personorganization fit and organizational commitment as mediators. International Journal of Economics and Management, 11(Special Issue 1), 45-57.

Saxena, S., \& Orley, J. (1997). Quality of life assessment: The World Health Organization perspective. European Psychiatry, 12(3), 263-266. https://doi.org/10.1016/S09249338(97)89095-5.

Sirgy, M. J. (2012). The Psychology of Quality of Life : Hedonic Well-being, Life Satisfaction \& Eudaimonia. New York: Springer.

Skevington, S. M., Lotfy, M., \& Connell, K. A. O. (2004). The World Health Organization 's WHOQOL-BREF quality of life assessment: Psychometric properties and results of the international field trial A Report from the WHOQOL Group q, 299-310.

Stamper, C. L., \& Johlke, M. C. (2003). The impact of perceived organizational support on the relationship between boundary spanner role stress and work outcomes. Journal of Management, 29(4), 569-588. https://doi.org/10.1016/S0149-2063(03)00025-4.

Sugiyono. (2013). Metode Penelitian Pendidikan Pendekatan Kuantitatif, Kualitatif, dan R\&D. Bandung: Alfabeta.

Theofilou, P. (2013). Quality of life: Definition and measurement. Europe's Journal of Psychology, 9(1), 150-162. https://doi.org/10.5964/ejop.v9i1.337.

WHOQOL SRPB Group. (2006). A cross-cultural study of spirituality, religion, and personal beliefs as components of quality of life. Social Science and Medicine, 62(6), 1486-1497. https://doi.org/10.1016/j.socscimed.2005.08.001.

World Health Organization. (1998). Draft Programme on Mental WHOQOL User Manual. World Health Organization, 1-106. https://doi.org/10.1007/SpringerReference_28001. 